\title{
Karakter Busana Kebesaran Raja Surakarta dan Yogyakarta Hadiningrat Periode 1755-2005
}

\author{
Ngatinah \\ Program Magister Desain - FSRD ITB
}

\begin{abstract}
Clothes represent cultural expressions and associate with certain social status. The Javanese societies, as complex as they are, possess unique social stratification according to the hierarchy of their positions, where the king has the tipmost status, followed by the nobles, merchants, farmers, and commoners. Thus, king clothes expresses societal status and cultural heritage of Java. This paper explores varieties of king clothes from the Surakarta and Yogyakarta kingdom on the period of 1755-2005, in order to identify the styles, associated symbolic meanings, and aesthetic values of the clothes whose patronage the Javanese people. The study focuses on the objects associate with king's clothes such as throne (kuluk/panunggul), sikepan bleggen, bordiran ageng, cinde/lancingan, blumbangan kampuh, wedhungpasikon, belt (ukup), kepuh, and footwear (selop). Results indicate that the king clothes of Surakarta and Yogyakarta were not made to solely express symbolic meanings but also to differ identities of the throned kings. Changes on the shape of the throne (kuluk or panunggul), coat (sikepan ageng bordiran bleggen), accesories, cinde pants (lancingan atau sarual), kampuh blumbangan with parang barong batik, short sword (pasikon wedhung), keris, belt (ukup) a pair of clothes on the back, and footwear (selop), can be used to characterize the throned kings and thus identities of them.
\end{abstract}

Keywords: king clothes; symbolic; meanings.

\section{Pendahuluan}

Keraton Surakarta dan Yogyakarta sebagai bekas sentra kekuatan politik, budaya dan adat, sampai sekarang masih memiliki mutiara-mutiara budaya yang adiluhung dan mengagumkan, walaupun mutiara-mutiara itu adalah peninggalan masa lampau yang bernafas kerajaan. Salah satunya adalah busana raja yang dianggap sebagai pusaka kerajaan yang memiliki nilai dan syarat makna. Nilai dan makna yang terkandung dalam tata busana kebesaran raja tersebut mewujudkan busana yang khas, indah dan anggun. Apabila busana tersebut dipakai, dapat diketahui siapa yang mengenakan, inilah salah satu kekayaan budaya kraton Surakarta dan Yogyakarta pada masa lampau, yang masih eksis sampai sekarang. 
Kraton Surakarta maupun Yogyakarta, keduanya merupakan buah hasil budaya yang telah lama menjadi simbol politik dan sosial budaya yang menduduki posisi paling penting dalam kehidupan masyarakat jawa. Memahami proses perkembangan pola kehidupan masyarakat Jawa di lingkungan istana, perlu dimengerti bahwa bagi alam pikiran orang Jawa, terbaginya kerajaan Mataram menjadi dua sebagai akibat perang suksesi yang dilakukan Pangeran Mangkubumi, adalah suatu kenyataan yang luar biasa. Peristiwa itu merupakan suatu peristiwa pengingkaran terhadap konsep kekuasaan dalam kebudayaan Jawa yang sring diungkapkan "endi ana surya kembar", yang merupakan manifestasi kekuasaan para penguasa kerajaan Mataram.

Raja pada masa kerajaan Mataram dikenal sebagai penguasa, sebagai pemimpin tradisi yang memiliki kharismatik (kemampuan khusus yang ada pada diri seseorang secara turun-temurun), dan berwewenang mutlak, sangat dihormati dan dipatuhi oleh rakyat, sehingga tercipta masyarakat yang aman dan tentram berwibawa dalam tradisi dan budaya yang tetap kuat dan sangat berpengaruh terhadap masyarakat.

Semenjak terbaginya wilayah Mataram tersebut segala perlengkapan untuk raja (isen-isen keprabon) yang berupa benda-benda artefak yaitu: pusaka, gamelan, titihan kereta, tandu /joli/ kremun, juga dibagi dua, termasuk busana corak Mataram yang dikehendaki oleh KP Mangkubumi di bawa ke Yogyakarta. Mengenai busana raja sebelumnya telah diwasiatkan oleh Pakoe BoewonoII kepada putranya; Pakoe Boewono III sebelum di angkat menjadi raja: " Mbesok manawa pamanmu Mangkubumi Hangersakake ageman, paringna" Artinya apabila kelak pamanmu Mangkubumi menghendaki busana, berikan saja, yang dimaksud busana di sini adalah busana kebesaran untuk kerajaan. Maka sejak itu busana Mataram diboyong ke Yogyakarta, seperti yang dapat dilihat hingga sekarang, selanjutnya S.I.S.K.S. Pakoe Boewono III membuat busana yang baru dengan Gaya Surakarta (gagrak Surakarta), termasuk kain batik untuk nyampingan coraknya mengalami perubahan-perubahan menyesuaikan dengan busana yang baru [1].

Sejak berdirinya, Karaton Surakarta dan Yogyakarta Hadiningrat, sampai sekarang telah berganti-ganti Sultan atau Raja yang memerintah dalam kurun waktu panjang $( \pm 250$ tahun $)$ tersebut tentulah di sana-sini mengalami perubahan mengikuti kondisi zaman, baik dalam kehidupan politik, ekonomi, dan sosial budaya.

Perubahan kedudukan dan fungsi Kasultanan Yogyakarta terjadi pada masa pemerintahan Sri Sultan Hamengku Boewono IX, melihat keadaan politik masa itu dan atas kesadaran Sri Sultan maka pada tanggal 18 Agustus 1945 sultan menyatakan sikap mendukung kepada Republik Indonesia serta sanggup berdiri 
di belakang kepemimpinan presiden dan wakil presiden Republik Indonesia. Wujud sikap mendukung tersebut pada tanggal 5 September 1945 Sultan Hamengku Buwono ke IX membuat amanat yang isinya menyatakan bahwa Kerajaan Yogyakarta adalah Daerah Istimewa yang merupakan bagian dari daerah Repunlik Indonesia, bahwa segala kekuasaan dan urusan pemerintah berada di tangannya dan hubungan Yogyakarta dengan Republik Indonesia bersifat langsung, serta bertanggung jawab langsung kepada presiden Republik Indonesia [2].

Keraton Surakarta dan Ngayogyakarta Hadiningrat berkuasa penuh walaupun menjadi bagian dari republik Indonesia, semua kegiatan atau budaya karaton masih tetap eksis seperti upacara-upacara adat kraton, antara lain: Gerebeg, labuhan, sungkeman. Serangkaian alat upacara adat karaton merupakan benda budaya kraton termasuk busana kebesaran raja yang dikenakan pada saat-saat acara kebesaran di lingkungan karaton. Busana kebesaran raja dikenal dengan istilah Ageman Keprabon.

Ageman Keprabon tersebut,terdiri dari Ageman Jumenengan, Ageman Pisowanan Bekda Jumeneng/Ngabekten Sepisan, Ageman Kirab/Keprajuritan, Ageman Kesatriyan Hageng/Selikuran, Ageman Siraman Pusaka Dalem, Ageman Ngabekten \& Muludan. Masing-masing dari busana tersebut di atas merupakan seprangkat busana yang terdiri dari : kupluk, sumping, beskap, slempang, sabuk, keris dan lancingan, kain batik motif parang barong dan selop.

Busana kebesaran raja, secara turun-menurun diwariskan dari Raja yang pertama kepada raja berikutnya, seiring dengan perubahan dan perkembangan situasi dan kondisi zaman dan masyarakat pendukungnya, berkaitan dengan situasi politik, ekonomi, maupun perkembangan nilai budaya pada saat itu baik untuk keraton Surakarta maupun keraton Yogyakarta Hadiningrat.

\section{Sejarah Dua Kerajaan Jawa}

Awalnya ketika Ki Pemanahan seorang Panglima Tamtama (Pasukan Khusus) Kerajaan Pajang yang tekun, berbakat, dan rajin melatih diri dalam kawruh kasampurnaan. Berkat jasa-jasanya terhadap Keraton Pajang sehingga dihadiahi tanah di Bumi Mataram seluas 800 karya (sekarya: $40.000 \mathrm{~m}^{2}$ ). Tanah yang masih hutan belantara tersebut dibuka untuk dibangun sebuah padepokan sebagai tempat meningkatkan kawruh kasampurnaan, tempat tinggal keluarga, dan pengikutnya. Bumi Mataram yang amat subur dan tidak kekurangan air jernih sehingga banyak pendatang baru menetap untuk mengolah tanah pada akhirnya mendirikan desa-desa baru. Mataram terus berkembang dalam kepemimpinan Ki Pemanahan yang dijuluki Ki Ageng Mataram yang dibantu 
oleh putra sulungnya yaitu Bagis Damar (putra angkat Sri Sultan Pajang). Sementara Ki Pemanahan menjadi Ki Ageng Mataram, maka Bagus Danar yang bergelar Raden Ngabei Sutowidjojo melaksanakan tugas sebagai Panglima Tamatama. Setelah Ki Ageng Mataram wafat, putra sulungnya yaitu Ngabei Sutowidjojo sebagai pengganti ayahnya menjadi pengemban wibawa Mataram, pewaris Bumi dan Panglima Tamtama yang diberi gelar Senopati Ing Ngalogo.

Setelah Sri Sultan Pajang Prabu Hadiwidjojo (Mas Karebet) wafat, semua atribut Kraton Pajang diserahkan kepada anak angkatnya yaitu Bagus Danar (Senopati Ing Ngalogo) untuk diboyong kediamannya Mataram sekaligus menjadi pengemban Keraton yang berarti kelahirannya Keraton Pajang dan mulailah Keraton Mataram di Kutagede Yogyakarta pada tahun 1586 [3].

Raja-raja Mataram sebagai berikut:

1. Panembahan Senopati Ing Ngalogo, putra dari Ki Ageng Mataram pada tahun 1586 - 1601.

2. Susuhubab Hadi Prabu Hanjokrowati, putra dari Penembahan Senopati Ing Ngalogo pada tahun 1601-1613.

3. Sultan Agung Prabu Hanjokrokosumo, putra dari Susuhunan Prabu Hadi Hanjokrowati pada tahun 1613 - 1645.

4. Susuhunan Hamangkurat I, putra dari Sultan Agung Prabu Hanjokrokosumo pada tahun 1646 - 1677.

Di bawah kepemimpinan Susuhunan Hamangkurat I terjadi pemberontakan dengan Trunodjojo yang mengakibatkan kekalahan Susuhunan hingga lari meninggalkan keraton. Sri Baginda meninggal di perjalanan dan dikebumikan di Tegalwangi sebelah selatan kota Tegal. Sebelum meninggal ia menyerahkan kekuasaannya kepada Pangeran Adipati Anom sebagai Susuhunan Amangkurat II. Trunodjojo dapat dikalahkan Susuhunan Amangkurat II dengan bantuan pasukan Belanda di bawah pimpinan Cornelis Speelman [4].

Susuhunan Amangkurat II bermaksud kembali ke Mataram namun keraton dalam keadaan rusak berat dan terlantar tidak terpelihara. Jakob Couper, pembesar Belanda di Jepara pernah menulis: "Ibukota Mataram lebih menyerupai hutan belantara dari pada pusat kerajaan..." (De Jonge VIII dalam Sajid [5]).

Runtuhnya Keraton Mataram akbiat peperangan tidak dimungkinkan untuk ditempati lagi, sehingga Susuhunan Amangkurat II memutuskan untuk memindahkan Keraton ke daerah lain. Melalui perundingan dengan para Patih, maka diputuskan kota Wanakerta yang terletak di daerah Pajang yang diubah menjadi Kartasura. 
Keraton Kartasura dalam pemerintahannya dipimpin oleh lima raja yaitu :

1. Susuhunan Amangkurat II, putra dari Susuhunan Hamangkurat I (16771703).

2. Susuhunan Hamangkurat III, putra dari Susuhunan Hamangkurat II (1703-1704).

3. Susuhunan Pakubowono I, putra dari Susuhunan Hamangkurat I (17041719).

4. Suhuhunan Hamangkurat IV, putera dari Susuhunan Pakubuwono I (1719-1727).

5. Susuhunan Pakubuwono II, putra dari Susunan Hamangkurat IV (17271745), selanjutnya pindah di Surakarta.

Pada pemerintahan Susunan Pakubuwono II terjadi adanya Perjanjian Giyanti. Menurut Moh. Dalyono [6] pada tanggal 13 Pebruari 1755 terjadi pemisahan kerajaan Mataram yang disebut perjanjian Giyanti di Gunung Lawu. Pemisahan kerajaan tersebut diprakarsai oleh Belanda dengan mengeluarkan surat perintah sebagai berikut:

Atas nama Kompeni Belanda Hartight dengan khidmat mengangkat Mangkubumi, dan Mahargyanya dengan gelar Sultan Hamengkubuwono Panatagama Senopati ing Ngalogo Ngabdulrahman Syahidin Panatagama Kalipatullah sebagai ibukota dipilihnya Yogyakarta dimana ia membangun keraton.

Pada perjanjian tersebut menerangkan bahwa di dalam Keraton Mataram terjadi dua wilayah kekuasaannya, yaitu mengangkat Mangkubumi sebagai raja setengah kerajaan dengan gelar Sultan Hamengkubuwono yang membangun Keraton Yogyakarta [6]. Berarti Keraton Matam terbagi menjadi dua wilayah yaitu di Yogyakarta bernama Kasultanan yang dipimpin oleh adiknya Susuhunan Pakubuwono II yaitu Sri Sultan Hamengkubuwono mertua dari R.M. Said, sedangkan di Surakarta bernama Kasunanan yang dipimpin oleh Susuhunan Pakubuwono II. Kedua wilayah tersebut berkembang hingga menambah dua wilayah kekuasaan lagi, yaitu di Surakarta bernama Kadipaten Mangkunegaran, dan di Yogyakarta bernama Kadipaten Pakualaman.

Setelah pecahnya Mataram menjadi dua wilayah Surakarta dan Yogyakarta, maka semua seragam yaitu busana kebesaran Raja dan keluarganya seperti motif Kawung dan busana lurik yang dipakai para Prajurit Dalem di boyong ke Yogyakarta. Kejadian inilah Keraton Surakarta menerapkan motif lain (selain motif Kawung), sebagai pengganti busana kebesaran Raja dan keluarganya yaitu motif Parang. 


\subsection{Keraton Surakarta Hadiningrat (Kasunanan)}

Sekitar tahun 1742 terjadi peperangan Cina di Jakarta, hingga merambat ke Jawa Tengah karena didesak oleh Belanda. Semarang mulai terkepung Cina yang menyebabkab tidak tentramnya Keraton Kartasura. Ketidak tentraman ini menjadi kenyataan hingga Keraton Kartasura diserbu oleh Cina yang dipimpin Sunan Kuning (Cucu Amangkurat III) yang mengakibatkan Susuhunan Pakubuwono II mengungsi ke Ponorogo (Lurah Tholik, Wawancara 10 Desember 1996).

Belanda yang berada di Semarang tidak berani berhadapan dengan Cina yang menguasai Keraton Kartasura. Namun Pangeran Cakraningrat dari Madura dan Raden Mas Sahid sangat marah karena kekuasaan Cina terhadap keraton Kartasura, sehingga mereka bermaksud untuk merebut kembali Keraton yang dibangun dengan susah payah tersebut. Kekuatan Pangeran Cakraningrat yang luas biasa tanpa bantuan Belanda, akhirnya dapat merebut kembali Keraton Kartasura. Susuhunan Pakubuwono II bermaksud kembali ke Keraton Kartosuro, tetapi keadaan rusak berat akibat perang, sehingga ia memutuskan untuk pindah ke tempat lain.

Untuk memilih tempat baru Susuhunan Pakubuwono II berunding dengan kerabat keraton dan bupati di daerah-daerah sewilayah Keraton kartasura. Dalam perundingan diusulkan tiga tempat yang telah diselidiki dan ditinjau dari berbagai sudut, yaitu : Desa Kadipolo (sekarang Taman Sriwedari), Desa Sala (komplek Keraton sekarang), dan Desa Sanasewu (sebelah barat Kecamatan Bekonan). Setelah dipertimbangkan secara matang, maka desa Sala terpilih untuk dibangun sebuah keraton pindahan dari Kartasura.

Menurut R.M. Sajid dalam Babad Sala [5], terpilihnya Sala dikarenakan pula oleh kehendak Suhunan Pakabuwono II, yang pernah berkata:

"Adipatu Pringgoloyo, karsaningsun ing mengko desa Sala ingsun pundhut jenenge desa Sala, ingsun karsakaken dadi negaraningsun, ingsun paringi jeneng ing nagara Surakarta Hadiningrat".

Menurut R.M. Sajid lagi, bahwa terpilihnya Sala karena mudah mendatangkan kayu jati dari Hutan Selatan, tidak kekurangan tenaga kerja, tidak kekurangan pangan karena dekat dengan Ponorogo dan kalau Raja utusan ke Gresik dan Surabaya bisa lewat Bengawan.

Tumenggung Tirtawiguna dan Pangeran Wijil ketika meheningkan cipta di Kedhung Kol terdengar suara gaib yang berbunyi: 
"He, wruhaniro, Yen sira kepingim golek papan anyar pandungane Keraton, coba mara terus ngetano nganti tekan desa Sala, awit Kang Maha Kuasa wis anjejekake desa mau bakal dadi kutha kang gedhe, gemah ripah loh jinawi...." [7].

Sebenarnya nama Sala sudah ada sejak Keraton Pajang, ketika dibawah kekuasaan Kanjeng Sinuwun Sultan Hadiwijaya. Lurah wilayah desa tersebut adalah Ki Gedhe Sala, maka desa tersebut dikatakan Sala. Pada tahun 1745 Keraton Kartasura pindah ke Sala bernama Keraton Surakarta Hadiningrat dengan Raja Susuhunan Pakubuwono II [5,8]. Nama Sura-Karta merupakan kebalikan dari Karta-Sura. Adapun Hadi-Ningrat mempunyai pengertian Hadi adalah lebihi, sedangkan Ningrat adalah mulya, besar, dan agung. Diharapkan Surakarta Hadiningrat supaya menjadi Keraton yanh lebih besar, mulya, dan agung. (Lurah Tholik. Wawancara, 10 Desember 1996).

Di Serat Pindah Kedhaton (dalam Mbangun Tuwuh [9]) disebutkan bahwa :

Sigra jenkar saking Kartasura,

Ngalih Kadhaton mring dhusun Sala,

Kebut sawadya balane,

Busekan sapraja gung,

Pinengetan Hangkate huni,

Hanuju hari Buda enjing wancinipun,

Wimbaning lek ping sapta wlas,

Sura Heje Kombuling Pudja Kapyarsi,

Ring Nata kang sangkala,

Nepipun dinten Rebo Pahing 17 Suro je 1670.

Artinya:

Keraton Kartasura cepat-cepat pindah menuju desa Sala dengan Negara berserta semua pengikutnya. Pada pemberangkatannya dicarikan hari yang baik, yaitu pada pagi hari tepatnya pada hari Rabu Pahing tanggal 17 Sura 1670 (Jawa) atau 17 Pebruari 1745.

Dalam pindahan ke Surakarta Susuhunan Pakubuwon II dikawal oleh pengikutnya dengan barisan kehormatan. Barang-barang yang dibawa ke Surakarta meliputi; gajah, dua buah pohon beringin (waringin kurung) yang ditanam di tengah alun-alun utara, pohon beringin Gung yang ditanam di Timur Laut dan Barat Laut, pohon beringin Wah yang ditanam kanan-kiri pintu masuh Alun-alun dari arah utara, dan Bangsal Pangrawit yang berada di tengah-tengah Sasana Sumewa (Pagelaran). Semua yang dibawa tersebut hingga saat ini (S.P.B XII) masih ada. 
Raja-raja yang pernah berkuasa di Keraton Surakarta Hadiningrat (Kasunanan) $[3,10]$ meliputi :

- $\quad$ S.P.B II (dari Kartasura) adalah putra S. Prabu Hamangkurat IV (17451749).

- $\quad$ S.P.B III adalah putra S.P.B. II (1749-1788).

- S.P.B IV adalah putra S.P.B. III (1788-1820).

- S.P.B V adalah putra S.P.B. IV (1820-1823).

- S.P.B VI adalah putra S.P.B. V (1823-1830).

- S.P.B VII adalah putra S.P.B. IV (1830-1858).

- S.P.B VIII adalah putra S.P.B. IV (1858-1861).

- S.P.B IX adalah putra S.P.B. VI (1861-1893).

- S.P.B X adalah putra S.P.B. IX (1893-1939).

- S.P.B XI adalah putra S.P.B. X (1939-1945).

- S.P.B XII adalah putra S.P.B. XI (1945-sekarang).

\subsection{Keraton Yogyakarta Hadiningrat (Kasultanan)}

Pada awal mulanya kerajaan Mataram adalah kerajaan yang berdaulat dan merdeka. Tetapi kedaulatan dan kemerdekaan kerajaan ini surut, setelah kerajaaan ini membuat perjanjian dagang dengan para pengusaha Belanda (VOC). Kemerosotan kedaulatan dan kemerdekaan kerajaan Mataram dimulai setelah meletusnya Geger Pacinan (1740-1743) di Surakarta. Pemberontakan orang Cina yang sempat berhasil menguasai Kartosura ibu kota kerajaan Mataram ini, membuka peluang bagi VOC atau nama persatuan perusahaan Hindia Timur milik Belanda untuk semakin menancapkan pengaruhnya kepada Susuhunan Paku Buwono II, dengan jalan menawarkan diri membantu menumpas pemberontakan orang Cina tersebut.

Atas jasa keberhasilannya menumpas pemberontakan Cina, VOC (Belanda/ Kompeni) diberikan hak monopoli perdagangan dan transportasi di wilayah kerajaan Mataram. Tetapi keputusan SUSuhunan Paku Buwono II ini, membuat salah seorang kerabat keraton yang bernama Raden Mas Sahid kecewa. Kekecewaan tersebut, membuat Raden Mas Sahid untuk memberontak guna mengubah keputusan Susuhunan. Karena Raden Mas Sahid terkenal kesaktiannya, maka tidak ada satria Mataram yang berani menghadapinya. Oleh karena itu, Susuhunan Paku Buwono II kemudian mengeluarkan maklumat, bagi siapa saja yang dapat menumpas pemberontakan Raden Mas Sahid akan diberi hadiah tanah Sukowati [11].

Satu-satunya ksatria Mataram yang sanggup untuk menumpas pemberontakan tersebut adalah Pangeran Mangkubumi (Raden Mas Sujono) adik dari Paku Buwono II sendiri. Pangeran Mangkubumi berhasil menumpas pemberontak ini, meskipun Raden Mas Sahid dan Pangeran Martapura pimpinan pemberontakan 
ini sempat meloloskan diri tetapi kelicikan Pepatih Dalem yang bernama Pringgo Loyo, agar membatalkan pemberian hadiah tersebut.

Maka atas pembatalan hadiah yang dilakukan Susuhunan Paku Buwono II ini, membuat Pangeran Mangkubumi kecewa. Kemudian Pangeran Mangkubumi beserta pengikutnya memutuskan untuk bergabung dengan Raden Mas Sahid dan Pangeran Martapura guna melakukan pemberontakan. Menghadapi pemberontakan yang dilakukan para kerabat dekat ini, Susuhunan Paku Buwono II telah meminta bantuan pihak VOC. Tetapi pada tahun 1749, sebelum perang saudara berakhir, Susuhunan Paku Buwono II wafat. Namun sebelum wafat raja sempat membuat perjanjian politik dengan VOC. VOC yang diwakili oleh Gubernur Van Hohendorff, berhasil membujuk Susuhunan untuk menandatangani sebuah perjanjian. Perjanjian ini dikenal dengan nama Kontrak 11 Desember 1749. Isi perjanjian tersebut antara lain, penyerahan kekuasaan kerajaan Mataram kepada pihak Kompeni (VOC). Untuk lebih jelasnya perjanjian tersebut berbunyi :

Kami, Sunan Paku Buwono Senopati Ingalogo Ngabdurrahman Sajidin Panotogomo mengakui dan menyatakan dengan ini secara terbuka, bahwa karena kami menderita sakit keras, maka kami tak mungkin memerintah kerajaan Mataram. Mengingat hal itu, maka kami menyerahkan segala kekuasaan kewibawaan dan kedaulatan, yang kami miliki hingga saat ini, kepada Kumpeni, yang dalam hal ini diwakili oleh Gubernur dan Direktur Jawa.

Kami melakukan penyerahan ini atas kehendak kami sendiri dengan maksud, agar Kumpeni dapat menyelenggarakan pemerintahan dalam kerajaan Mataram untuk kepentingan kerajaan Mataram dan rakyatnya.

Sekalipun Tuhan Yang Maha Esa akan menyembuhkan penyakit kami dan kami akan diberi karunia untuk dapat hidup beberapa tahun lagi, kami sudah tidak akan turut campur lagi dalam pemerintahan kerajaan, malainkan hanya kehendak untuk hidup dengan tenang dan tentram.

Kami mengharapkan dari Kumpeni, untuk memberi perlindungan terhadap anak-anak kami terutama Pangeran Adipati Anom. [12]

Dengan perjanjian politik ini maka telah hilanglah kedaulatan dan kemerdekaan kerajaan Mataram sejak itu, VOC lah sebagai penguasa kerajaan Mataram dan yang berhak mengangkat siapapun menjadi raja. Untuk mengisi kekosongan 
kedudukan raja Mataram maka diangkatlah Pangeran Adipati Anom sebagai Susuhunan Paku Buwono III oleh VOC.

Dengan perjuangannya selama 9 tahun Pengeran Mangkubumi dengan dibantu Raden Mas Sahid, akhirnya berhasil memaksa Susuhunan Pakubuwono III dan VOC untuk menyerahkan separuh wilayah kerajaan Mataram kepada Mangkubumi. Oleh karena itu dibuatlah perjanjian damai antara Pangeran Mangkubumi, Pakubuwono III dan pihak Belanda (VOC). Perjanjian perdamaian yang ditandatangani di desa Gianti pada tanggal 13 Februari 1755 ini memutuskan bahwa kerajaan Matram dibagi menjadi dua kerajaan, yakni Kraton Surakarta dan Kraton Yogyakarta. Setelah resmi menjadi Kesultanan Yogyakarta, Pangeran Mangkubumi dinobatkan menjadi Sultan dengan gelar Sultan Hamengku Buwono Senopati Ing Ngalaga Ngabdurrahman Sayyidin Panatagama Kalifatullah I [12]. Sedangkan menurut Soekanto bahwa dalam perjanjian tersebut, dinyatakan bahwa:

Setelah meninggakan istana Surakarta pada tahun 1746, Pangeran Mangkubumi telah kembali untuk mencari perlindungan kepada VOC berdasarkan saran berkali-kali dan sungguh-sungguh dari Gubernur dan Direktur Pantai Utara jawa, maka pemuka ini yang bertindak atas nama VOC memaafkan dan melupakan semua tindakan agresif melawan VOC, dan telah memutuskan untuk mengangkatnya sebagai Sultan atas separuh dari kerajaan Dataran Tinggi Jawa dan menjadikan sebagai penguasa Kerajaan tersebut di samping Susuhunan, masing-masing melaksanakan kekuasaan atas tiap propinsi dan kabupaten yang diserahkan kepadanya Perjanjian yang memecah wilayah kerajan Mataram menjadi dua bagian ini, tidak hanya menyangkut tanah dan rakyat, tetapi juga membagi tanda-tanda kebesaran kerajaan yang berupa lambang kekuasaan maupun pusaka-pusaka yang mempunyai kekuaran magis, yang tidak dipisahkan dari raja yang memerintah [13].

Keraton Kesultanan Yogyakarta terletak di tengah-tengah kota Yogyakarta. Dahulu wilayah yang termasuk daerah keraton adalah daerah yang terbentang di antara sungai Winongo dan sungai Code. Berbatasan Tugu di sebelah utara dan Krapyak di sebelah selatan [14]. Sedang bila menilik nama-nama kampung yakni Patangpuluhan, Ketanggungan, Wirobrajan, Sindurjan, Bugisan di bagian barat sungai Winongo, kemungkinan besar perluasan wilayah ini bersamaan dengan berdirinya keraton Yogyakarta. Sebab nama kampung-kampung tersebut menunjukkan tempat golongan prajurit Pangeran Mangkubumi yang menahan serangan musuh dari arah barat, seperti: prajurit Ketanggung, Wirobrojo, Patangpuluh, Sindurejo dan prajurit Bugis. Demikian juga nama-nama kampung disebelah timur sungai Code seperti: Kampung Nytran dan Surokarsan untuk melindungi serangan dari arah timur. Pada pertahanan sebelah selatan ditempatkan prajurit Daeng, Jogoroyo, Prawirotomo dan Mantrijero [12]. 
Perkembangan selanjutnya kerajaan Yogyakarta ini pecah lagi menjadi dua yaitu kraton Yogyakarta dan Paku Alaman pada tahun 1811 hingga 1815. perpecahan ini terjadi pada masa pemerintahan Sultan Hamengkubuwono II. Karena sifat sombong dalam kepemimpinannya, maka banyak muncul pergerakan baik dari dalam istana maupun luar istana untuk menghadapi sultan. Pemberontakan melawan Sultan bahkan datang dari putra mahkota sendiri.

Selain itu kedatangan Inggris banyak juga berperan terhadap perpecahan kerajaan Yogyakarta, sebab kedatangan penjajah Inggris di Hindia Belanda ini bersamaa waktu dengan timbulnya gerakan anti penjajah di kerajaan Yogyakarta dan Surakarta. Dengan harapan untuk mengurangi kekuatan kerajaan Yogyakarta, maka pemerintah Inggris menggunakan kesempatan ikut campur dalam perselisihan antara Hamengkubuwono II dan putranya tersebut. Penjajah Inggris kemudian menyerang kerajaan Yogyakarta dan berhasil menangkap Sri Sultan Hamengku Buwono II dan menyingkirkannya ke Pinang. Putra mahkota kemudian naik tahta, dengan gelar Hamengkubuwono III. Keberhasilan menyingkirkan Hamengkubuwono II atas bantuan Pangeran Natakusuma, maka Gubernur pemerintah Inggris, Thoman Stamford Raffles telah mengangkat Pangeran Natakusuma sebagai kepala pemerintahan pada daerah Paku Alaman. Paku Alaman merupakan bagian wilayah kerajaan Yogyakarta yang dihadiahkan kepada Pangeran Natakusuma, putra Sultan Hamengkubuwono I. Selain diberi hadiah sebagian kecil wilayah kerajaan Yogyakarta, Pangeran ini juga diakui sebagai pangeran yang merdeka, terlepas dari kekuasaan Kraton Yogyakarta. Setelah dinobatkan menjadi penguasa Kadipaten Pakualaman, Pangeran ini kemudian bergelar Paku Alam I.

Pembagian wilayah Yogyakarta tersebut, kemudian diteruskan dengan perjanjian politik pada tanggal 17 Maret 1813 antara Pangeran Paku Alam dengan pemerintah Inggris. Perjanjian tersebut menyebutkan :

"Oleh karena Pemerintahan Inggris terkesan oleh rasa kesetiaan, keterikatan dan pengabdian Pangeran Paku Alam yang tinggi, maka dengan ini mereka dengan senang hati melindunginya beserta keluarganya..." [15].

Perlindungan Gubernur Inggris Raffles atas Paku Alam ini juga tertuang dalam perjanjian yang disyahkan pada tanggal 11 Agustus 1812, yang menyatakan bahwa :

"Pangeran Notto Coesoemo, Pakoe Alam, karena bermaksud mengabdi pada pemerintah Inggris, Yang Mulya Sultan berjanji tidak akan menghalanginyadan berjanji untuk tidak menggangu keluarga maupun pengikutnya. [15] 
Maka ketika penjajah Belanda kembali datang pada tahun 1816, kerajaan Mataram telah terpecah menjadi empat kerajaan yaitu: Surakarta, Mangkunegaran, Yogyakarta, dan Pakualaman. Pemerintah Belanda kemudian menunjuk beberapa orang residen untuk mengawasi empat kerajaan tersebut. Walaupun kekusaan utama Sultan maupun Susuhunan telah surut akibat perjanjian politik dengan Belanda, namun rakyat masih menunjukkan kesetiaan dan ketaatan kepadanya. Hubungan perjanjian politik ini tetap berlaku sampai kekuasaan penjajah Belanda di Hindia Belanda runtuh pada tahun 1942 akibat kekalahan dalam pertempuran melawan pihak Jepang.

Secara fisik, keraton Yogyakarta dibangun oleh Sultan Hamengkubuwono I tahun 1756 atau tahun Jawa 1682. Hal ini dibuktikan dengan adanya sebuah Condrosengkolo memet di pintu gerbang Kemanganan dan pintu gerbang Gadung Mlati, berupa dua ekor naga berlilitan satu sama lainnya.

Dalam bahasa Jawa: Dwi Naga Rasa Tunggal. Artinya Dwi $=2$, Naga $=8$, Rasa= 6 dan Tunggal $=1$. Dibaca dari belakang menunjukkan tahun 1682 [14].

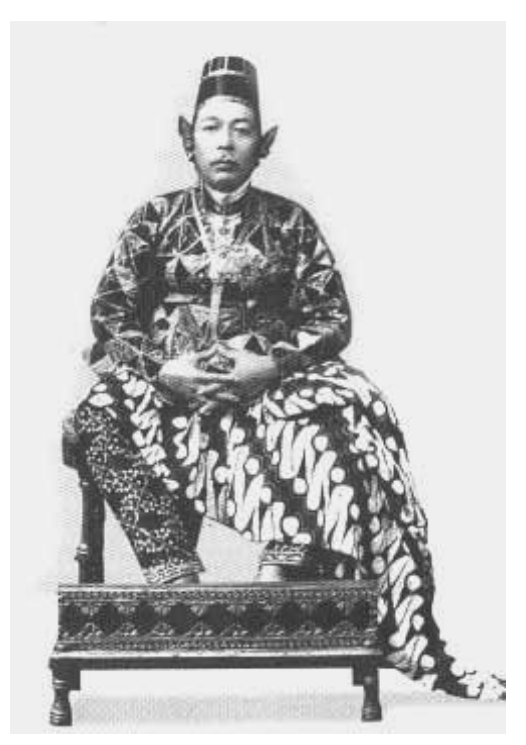

(a)

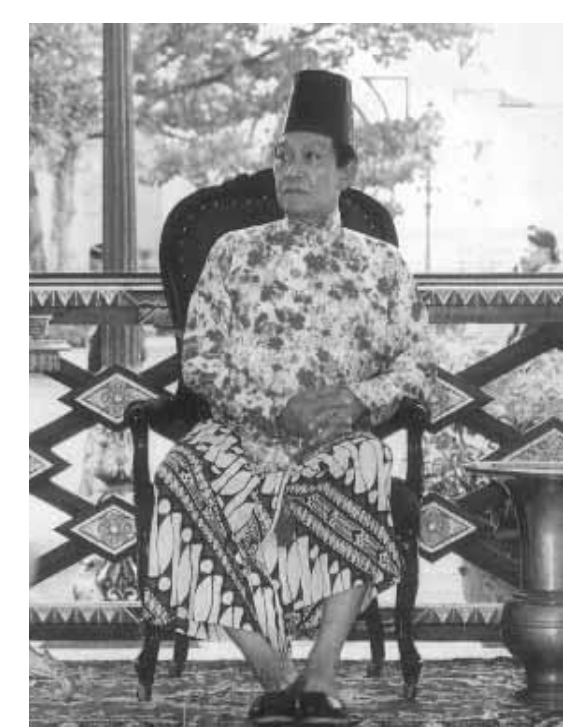

(b)

Gambar 1 (a) Busana bagian atas Sultan Hamengku Buwono VIIYogyakarta berupa jas model Barat (royal jacket) yang disebut sebagai Kyai Antakusuma untuk penahan bala dengan bawahan batik Parang Rusak; (b) Busana yang dikenakan oleh Sultan Hamengku Buwono X, mengenakan pakaian dengan ragam hias stilasi 'bunga' modern dengan bawahan memakai kain batik. 
Transisi menuju moderisasi terjadi di Yogyakarta sejak masa kepemimpinan Sultan Hamengku Buwono VII yang melihat manfaat dari pendidikan modern sehingga Sultan mendirikan sekolah-sekolah modern dan mengirimkan putraputranya ke negeri Belanda untuk menuntut ilmu. Ketika itu aktivitas pergerakan kebangsaan banyak bermunculan di Yogyakarta yaitu Kongres I Budi Utomo, pemogokan buruh yang digerakan sarekat Islam yang di pimpin Raden Mas Suryapranata (kakak Ki Hajar Dewantara) serta berdirinya pusat Muhammadiyah.

Pada masa kepemimpinan Hamengku Buwono VII banyak didirikan pabrik gula di Yogyakarta, seluruhnya berjumlah 17 pabrik. Setiap pendidikan pabrik memberikan peluang pada Sultan untuk menerima dana yang cukup besar dan ini mengakibatkan Sultan sangat kaya sehingga sering dijuluki Sultan Sugih . Dengan dana yang terkumpul ini, memungkinkan sultan untuk membiayai pembangunan dan perbaikan di lingkungan Keraton.

Pada masa pemerintahan Sultan Hamengku Buwono VIII yang dinobatkan pada tahun 1921, Kasultanan Yogyakarta mempunyai dana yang cukup besar untuk membiayai kegiatan-kegiatan termasuk membiayai sekolah-sekolah Kasultanan. Putra-putranya disekolahkan sampai tingkat perguruan Nasional Tamansiswa pada tanggal 3 Juli 1922 dan kemudian berdiri perkumpulan politik Katholik Jawi (1923) serta para Ibu mengadakan kongres Perempuan (1929).

Pada masa kecil Sultan Hamengku Buwono IX bernama Raden Dorojatun. Sejak berumur 4 tahun Dorojatun dititipkan pada keluarga Belanda untuk mendapatkan pendidikan yang maju. Pendidikannya disekolah-sekolah di Indonesia dan Belanda membentuk kepribadian nasionalis, wawasan yang modern dan pandangan demokratis yang mendukung perubahan-perubahan pada kehidupan Keraton yang feudal. Dorojatun naik tahta tanggal 18 Maret 1940 dan bergelar Sultan Hamengku Buwono IX.

Kebijakan-kebijakan sultan Hamengku Buwono IX mengenai kehidupan Keraton mencerminkan wawasannya yang modern dan demokratis dengan membuka keraton untuk seluruh rakyat yaitu tahun 1946 Universitas Gajah Mada berdiri dan menyediakan bangunan di lingkungan keraton sebagai tempat penyelenggaraan pengajaran yang kemudian diikuti oleh golongan bangsawan lainnya menyediakan rumah-rumahnya mereka yang cukup besar sebagai tempat pendidikan. Selain keraton dibuka untuk rakyat dalam bentuk tempat pendidikan, sultan juga membuka keraton sebagai tempat wisata karena kesadaran akan pentingnya pelestarian warisan budaya bangsa dan sebelum tahun kunjungan wisata 1991 keraton Yogyakarta dibuka untuk umum. 
Pemerintah Indonesia dalam masa pembangunan ini memberi kepercayaan pada Sri Sultan Hamengku Buwono X yang masih memiliki kharisma yang kuat untuk memimpin masyarakat Yogyakarta menuju kehidupan di masa datang. Hal ini dinilai sejalan dengan aspirasi masyarakat Yogyakarta yang sangat menghormati pemimpinan tradisinya. Keadaan ini dikemukakan juga oleh Max Weber dalam teorinya tentang kecenderungan dari kewenangan khasismatis (yang berkurang kekuatannya bila keadaan masyakarat berubah) untuk dijadikan kekuasaan tetap dengan mengabadikan kepentingan serta cita-cita para pengikut kharismatis tadi ke dalam kehidupan bersama kelompok dan kepentingan untuk mempererat hubungan satu dengan lainnya. (Weber, dalam [16]).

Pada masa kepentingan Sultan Hamengku Buwono VII dan Hamengku Buwono VIII, Keraton mengalami perubahan yang paling berarti secara fisik seperti perbaikan-perbaikan dan pemekaran bangunan yang erat kaitannya dengan penambahan kebutuhan. Perbaikan dilakukan terutama setelah terjadinya gempa bumi di Yogyakarta 1867 yang mengakibatkan beberapa kerusakan pada bangunan-bangunan di Keraton.

Pada masa sultan Hamengku Buwono VII ruang-ruang upacara di Keraton mengalami pemugaran besar-besaran yang menekankan peran keraton sebagai institusi seremonial. Sejumlah bangunan baru yang besar dan penting di antaranya adalah bangsal Siti Hinggil dan Tratag pagelaran daua banguna yang paling depan tempat sultan menyelenggarakan sidang raya pada saat Garebeg ini dibangun kembali dengan kontruksi dan elemen arsitektur yang dengan jelas mendapat pengaruh Barat.

Pada perayaan Garebeg pada bupati hadir untuk mempersembahkan hasil bumi yang melimpah di pelataran alun-alun dan masing-masing menempati bangunan yang disediakan dipelataran tersebut. Pada masa kepemimpinan sultan Hamengku Buwono VIII pelataran tersebut tinggal sepenggal kecil dibandingkan awal masa kerajaan Mataram wilayah lainnya telah disewakan. Kebiasaan para bupati untuk menghadap dan menunjukan kesetiaan pada sultan pun telah dihilangkan dan bersamaan dengan itu hilang juga bangunanbangunan semi permanen yang berbeda di pelataran alun-alun.

Pameran kemegahan yang semula melalui upacara yang sifatya temporer sekarang beralih melalui bangunan yang permanen. Tratag Siti Hinggil dan Tratag Pagelaran menjadi sosok yang paling monumental. Pameran hasil kesuburan bumi digantikan oleh ornamen sayur-mayur dan buah-buahan yang menghiasi segenap pemukaan tegak Tratag Pegelaran. 


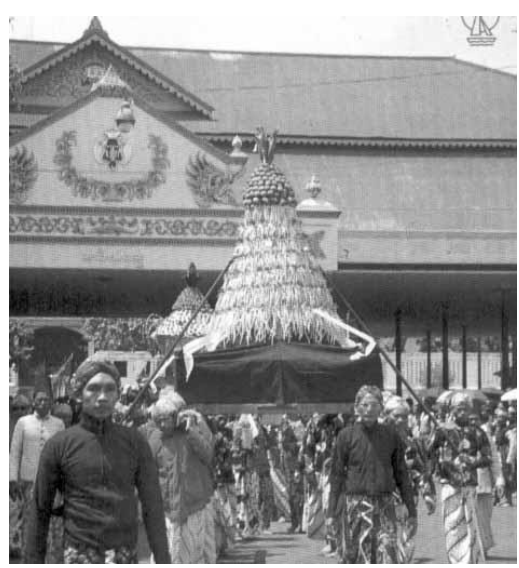

Gambar 2 Para pengiring Grebeg di Keraton Yogyakarta mengenakan busana bawahan kain batik sebagai bagian ritual yang tak terpisahkan.

Perubahan fungsi Keraton yang awalnya bersifat tertutup dengan adanya kebijakan sultan Hamengku Buwono IX tersebut menjadi terbuka dan secara fisik arsitektur keraton juga mengalami perubahan. Area Siti Hinggil yang terdapat bangunan permanen yaitu bangsal Manguntur Tangkil sebgai tempat Sultan duduk serta Bangsal Witana tempat pusaka-pusaka keraton diletakan selama upacara Garebeg berlangsung Tratag Siti Hinggil dan Tratag Pagelaran hanya berupa bangunan semi permanen hal tersebut menekankan fokus ritual yang menunjukan bahwa yang berkuasa adalah sultan dan pusaka-pusakanya. Sejalan dengan perkembangan kebutuhan maka Tratag Siti Hinggil dan Tratag Pegelaran dibangun kembali secara permanen dan bangsal Witana sekarang ini beralih fungsi menjadi ruang pamer berupa diorama suasana pada upacara Garebeg. Saat ini area Siti Hinggil merupakan arena terbuka dan menjadi area yang dapat dikunjungi oleh wisatawan.

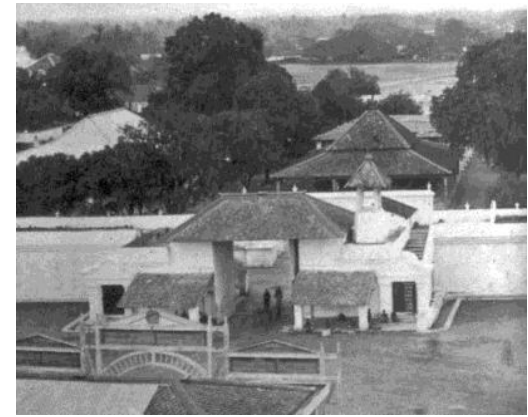

(a)

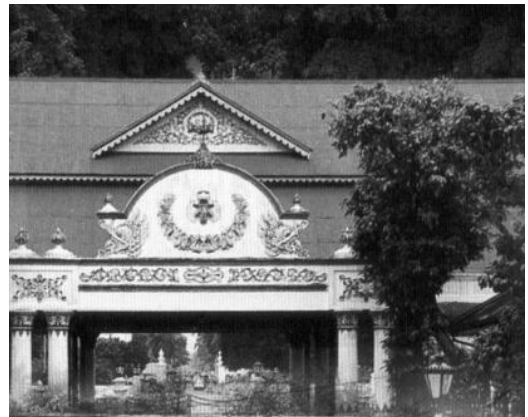

(b)

Gambar 3 (a) Keraton Solo; (b) Keraton Yogyakarta. 


\subsection{Busana Raja Keraton Surakarta dan Yogyakarta}

Perkembangan batik, diawali oleh kehadiran kain tenun bermotif batik sebagai tradisi dalam kebudayaan India yang datang ke Indonesia sejalan dengan masuknya agama Hindu-Budha. Diperkirakan tiba ke wilayah Nusantara sekitar abad ke-7 pada zaman keemasan kerajaan Sriwijaya. Kain tenun yang berasal dari India tersebut dikenal sebagai kain patola berasal dari pantai Gujarat dan kain sembagi (chintz) berasal dari pantai Koromandel. Kedua jenis kain ini umumnya banyak digemari oleh raja-raja Sumatera dan Jawa serta para bangsawan nusantara pada umumnya. Di awal abad ke-19, ketika kain patola mulai langka dikarenakan menurunnya perdagangan tekstil dengan India sejak abad ke-18, kemudian berkembang kain dengan teknik 'nitik' menggunakan canting tulis yang diisi malam (lilin yang dicairkan). Awalnya teknik membatik tersebut hanya meniru motif hias yang terdapat pada kain patola dari India. Namun akhirnya berkembang secara luas, baik di lingkungan keraton, terutama karaton di Surakarta, Yogyakarta dan Cirebon, kemudian meluas ke daerah pantai utara Jawa.

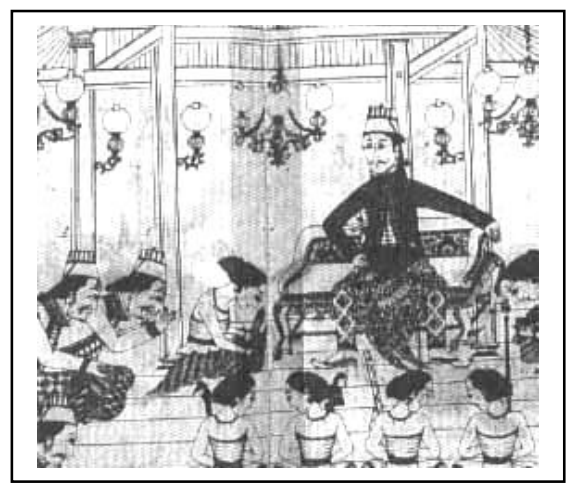

(a)

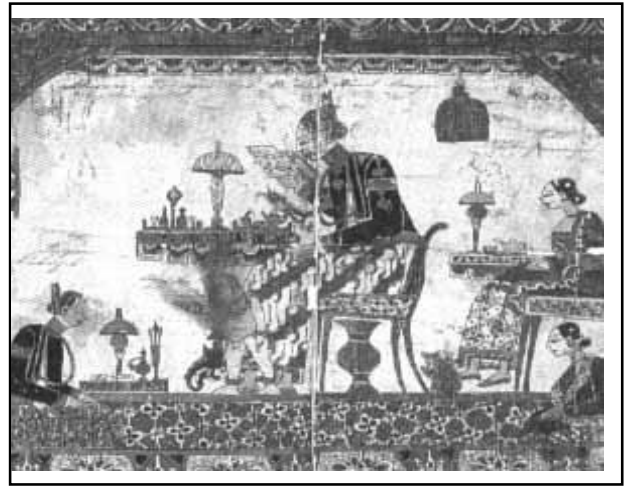

(b)

Gambar 4 (a) Ilustrasi yang menggambarkan Sri Susuhunan Pakubuwono II (1726-1749) sedang duduk di singgasana mengenakan kain batik sedang menerima Adipati Natakusuma, Arya Pringgalaya dan Tumenggung Tirtawiguna. (b) Ilustrasi yang menggambarkan Pangeran Diponegoro sedang membaca mengenakan busana tradisi dan kain batik, ilustrasi ini koleksi Snouck Hugronye.

Meluasnya pemakaian kain batik di masyarakat, baik di kalangan para bangsawan dan lingkungan keraton maupun rakyat jelata menumbuhkan pengrajin dan perdagangan batik di Jawa. Dalam penggunaan yang lebih spesifik, kain batik juga dikenakan oleh para penari tradisional, serta menjadi pelengkap pelbagai seni pertunjukkan lainnya. Di kalangan rakyat jelata, kain batik juga berfungsi ganda, tidak hanya sekadar busana sehari-hari, tetapi juga kerap dipergunakan untuk menggendong anak dan barang. 
Semenjak berdiri kerajaan Jawa kemudian melahirkan sejumlah simbol dan atribut-atribut kerajaan, di antaranya yang utama adalah 'busana kebesaran raja'. Kemunduran dalam bidang politik keraton akibat kolonialisme tidak berarti merupakan kemunduran dan kemorosotan wibawa raja. Realisasi peningkatan prestasi keraton dilakukan dengan melahirkan karya-karya besar di bidang sastra, atau dengan mempertegas perbedaan penampilan dengan rakyat biasa. Di antaranya mengembangkan corak busana atau pakaian yang memiliki ciri tersendiri. Busana adat kebesaran yang dipergunakan pada upacara-upacara kerajaan dapatlah dilihat sebagai simbol identitas yang terkait dengan hak dan kewajiban pemakainya [17].

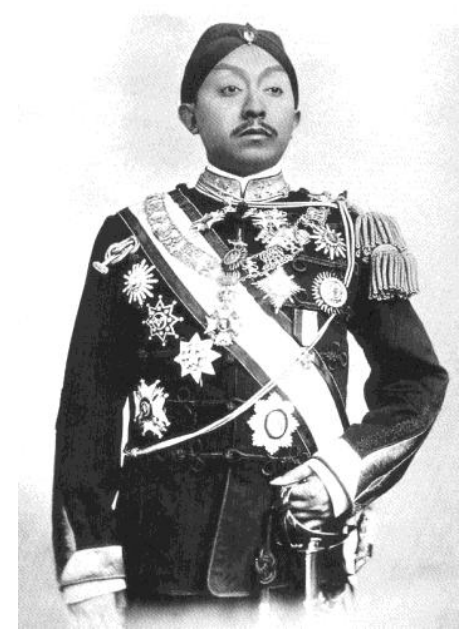

(a)

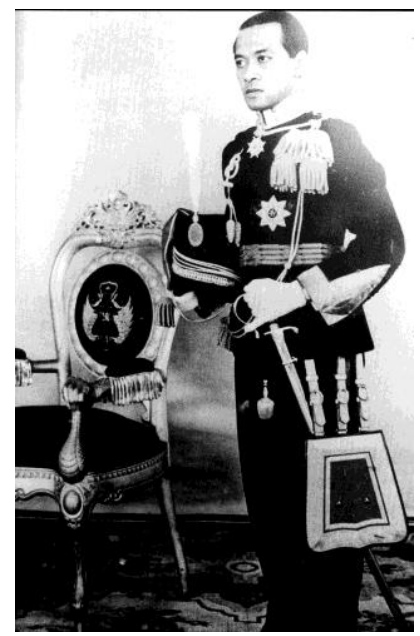

(b)

Gambar 5 (a) Pakaian kemiliteran Pakubuwana X; (b) Pakaian kemeliteran Sultan Hamengkubuana IX.

Walaupun Keraton telah mengalami alih fungsi dari pusat seluruh kehidupan sosial menjadi pusat kebudayaan, namun kebesaran dan kewibawaan keraton terlestarikan pada adat isitiadat budaya keraton dan upacara-upacara kebesaran keraton [18]. Dari adat istiadat inilah tumbuh dan berkembanglah nilai-nilai atau norma-norma yang menjadi panutan dalam masyarakat Jawa.

Busana adat keraton merupakan salah satu sarana dan pelengkap yang dipergunakan di dalam upacara kerajaan sarat dengan simbol-simbol atau perlambangan. Busana adat keraton juga dipakai oleh masyarakat lingkungan keraton dan mencerminkan kedudukannya sebagai abdi dalem dari pemakainya. Bagi masyarakat keraton dalam hal berbusana terdapat suatu aturan yang yang menentukan baik dalam pemakaian, motif maupun model busana yang 
dikenakan. Aturan-aturan ini disesuikan dengan pangkat dan tingkat status sosialnya di dalam kehidupan masyarakat kraton. Busana kebesaran keraton hingga sekarang tetap dipertahankan sebagai dukungan wibawa sipemakainya. Apalagi jika busana itu dilengkapi dengan sejumlah asesoris mewah, mahal serta pelengkap busa lainnya yang hanya dimiliki oleh beberapa orang saja. Kenyataan tersebut pada dasarnya memperlihatkan adanya sifat superioritas/ keunggulan seseorang dalam sebuah stratum sosial masyarakatnya [19].

Busana adat bagi para bangsawan kraton pada mulanya berupa kain batik. Kain batik pada masa itu masih merupakan barang mewah, dan hanya dipakai oleh kalangan para bangsawan maupun masyarakat kelas atas, sebab hanya merekalah yang dapat membeli. Kain batik sebagai karya seni kerajinan kalangan istana telah dimulai dan berkembang pada zaman Hindu. Seni sebagai karya seni istana pada zaman Islam mengalami perkembangan baru. Perkembangan ini disesuaikan dengan pengembangan dan peningkatan teknik membatik dengan cara yang khas. Menurut para ahli, motif batik adalah salah satu bentuk kebudayaan asli Indonesia. Pernyataan ini berdasarkan penyelidikan istilah-istilah batik dan bahan serta teknik yang tidak dijumpai misalnya pada batik India atau Persia. Motif-motif batik yang sudah dikenal sejak zaman pra sejarah di wilayah Nusantara juga memperkuat bukti keaslian dari seni kerajinan ini [20].

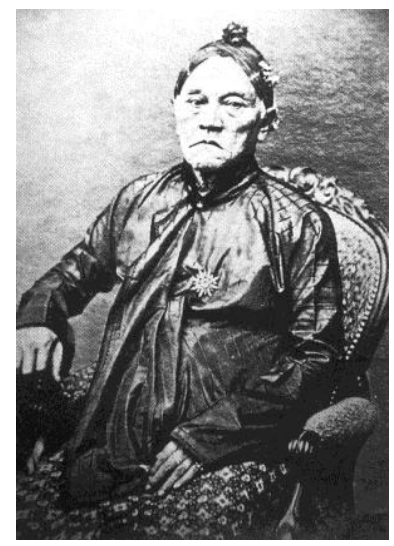

(a)

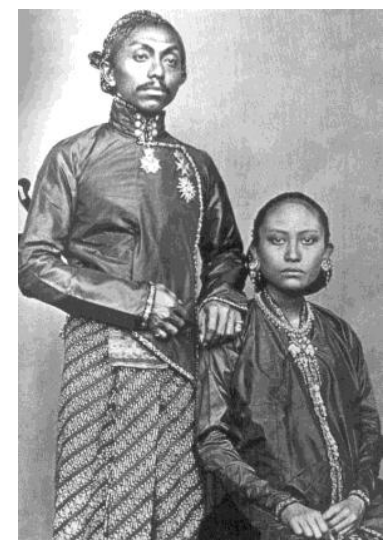

(b)

Gambar 6 (a) Pakaian sehari-hari Paku Buwono VIII; (b) Pakaian sehari-hari Paku Buwono IX.

Sebagaimana dipaparkan di atas, bangsa Indonesia telah mengenal teknik pembuatan batik sebelum masuknya pengaruh India. Perkembangan disain batik di Indonesia telah mencapai kesempurnaan pada abad $14-15$, sedangkan di India baru dapat mencapai antara abad 17-18. pendapat ini semakin kuat dengan 
adanya bukti yang terdapat pada arca dan relief candi di Indonesia mulai abad IX, yang melukiskan ornamen kawung, lereng, ceplok dan motif cindhen [21].

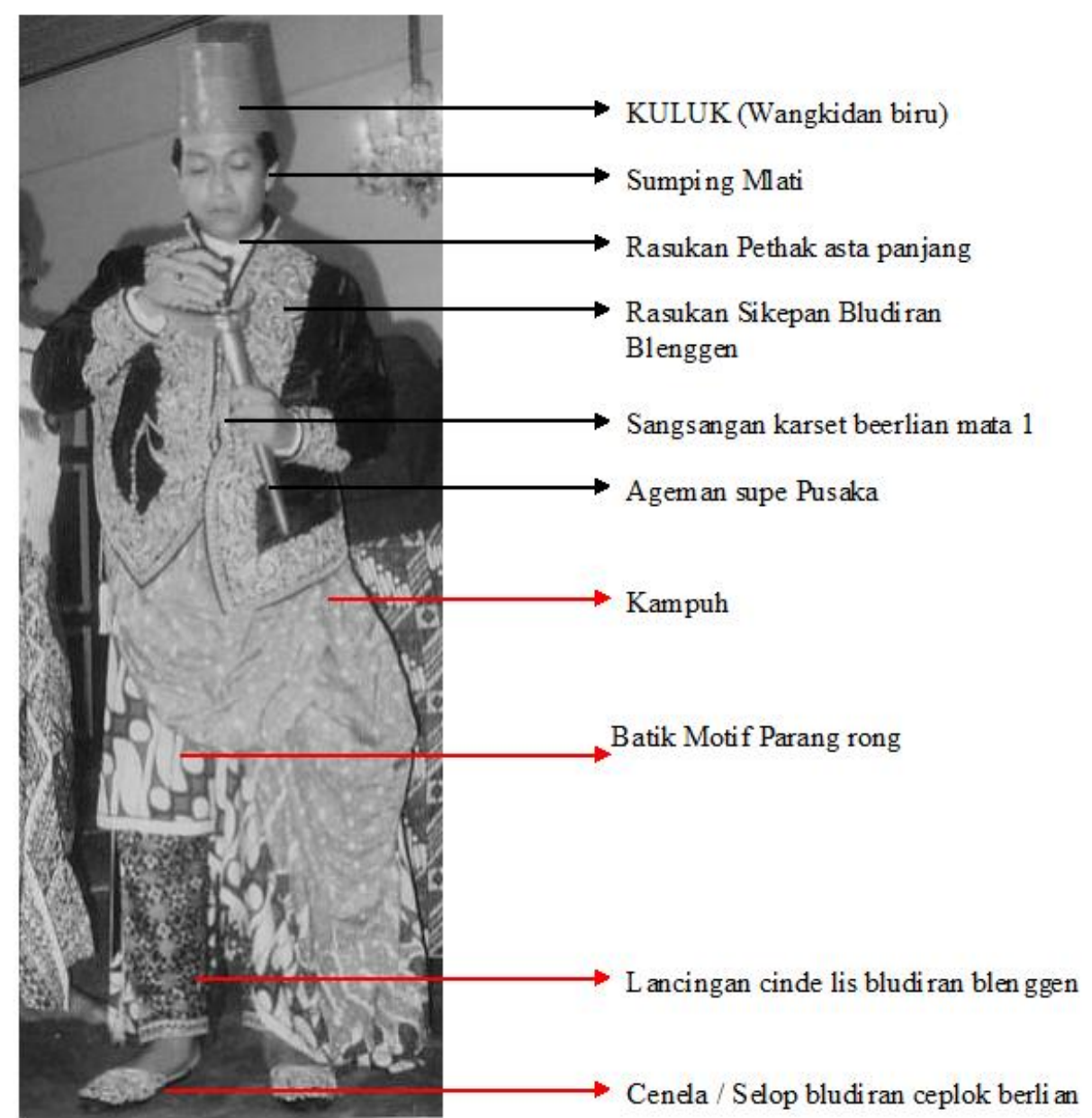

Gambar 7 Pakaian Kebesaran Sultan Hamengku Buwono X.

Pada masa itu batik merupakan pakaian dari golongan ningrat atau kalangan istana saja. Di dalam busana adat keraton pola garis dan mode kain batik merupakan hal yang penting dalam menentukan tata cara berbusana adat keraton. Di Keraton Yogyakarta, Sultan Hamengkubuwono I pada tahun 1785 mencanangkan pola parang rusak sebagai pola larangan di wilayah kesultanan. 


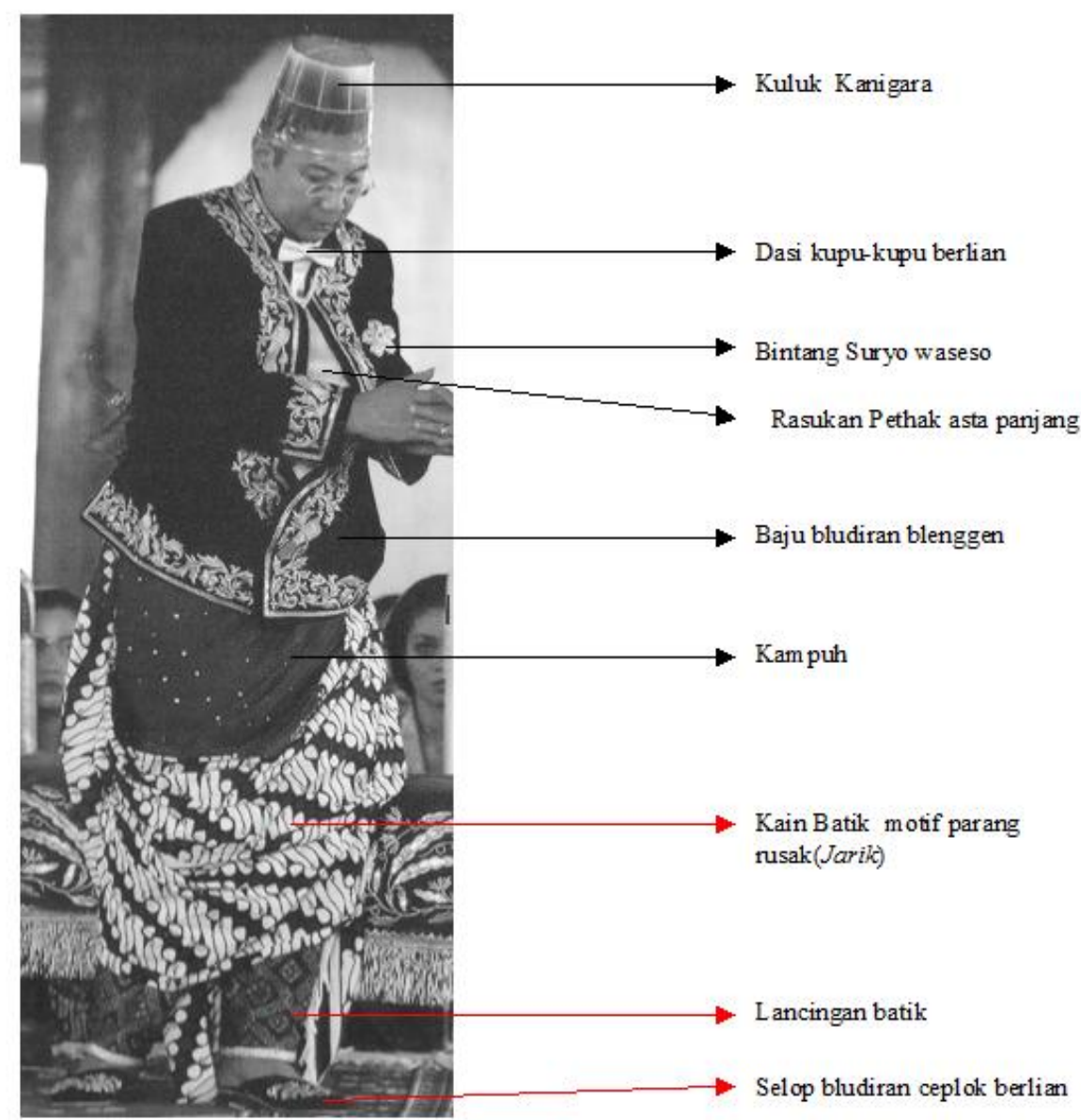

Gambar 8 Pakaian Kebesaran Paku Buono XIII.

Corak parang bermotif pedang ini melambangkan kekuasaan dan gerak cepat, oleh karenanya pemakai diharapkan dapat bergerak cepat dan gesit. Garis-garis lengkung pada motif parang melambangkan ombak lautan sebagai pusat tenaga alam, hal ini yang dimaksudkanadalah raja [17]. Jenis motif parang meliputi : parang barong, parang rusak, parang gendreh, dan parang klitik. Corak batik larangan lainnya adalah motif huk dan kawung. Motif huk terdiri dari motif kerang, bintang, cakra, burung, sawat dan garuda. Motif kerang merupakan lambang dari air atau dunia bawah yang bermakna lapang hati. Bintang menggambarkan watak sentosa dan pemberi kemakmuran. Motif burung huk sebagai simbol kepemimpinan dan berbudi luhur, sedang motif sawat merupakan ungkapan ketabahan hati [17]. Dan karena raja adalah pimpinan 
tertinggi kerajaan, maka batik motif huk hanya boleh dikenakan seroang raja dan putra mahkota [22].

Secara garis besar busana adat keraton menurut Mari S. Condronegoro dapat dibedakan menjadi dua golongan yaitu busana untuk kegiatan sehari-hari atau kegiatan non formal dan kegiatan untuk yang formal/ resmi. Busana resmi ini terdiri dari busana untuk kegiatan upacara alit dan busana untuk kegiatan upacara ageng.

Tabel 1 Perkembangan Busana Kebesaran Raja Surakarta Dari Pakubuwono ke IX-XIII.

\begin{tabular}{|c|c|c|c|c|c|}
\hline Nama & 1 & 2 & 3 & 4 & 5 \\
\hline Bentuk & $\begin{array}{c}\text { PB IX } \\
\text { 1861-1893 }\end{array}$ & $\begin{array}{c}\text { PB X } \\
1893-1939 \\
\end{array}$ & $\begin{array}{c}\text { PB XI } \\
\text { 1939-1945 }\end{array}$ & $\begin{array}{c}\text { PB XII } \\
1945-2004\end{array}$ & $\begin{array}{c}\text { PB XIII } \\
\text { 2004-Skrng. }\end{array}$ \\
\hline $\begin{array}{l}\text { Busana Raja } \\
\text { secara } \\
\text { keseluruhan }\end{array}$ & & & & & \\
\hline
\end{tabular}

Tabel 2 Perkembangan Busana Kebesaran Raja Yogyakarta Dari Hamengku Buwono ke VI-X.

\begin{tabular}{|c|c|c|c|c|c|}
\hline Nama & 1 & 2 & 3 & 4 & 5 \\
\hline Bentuk & $\begin{array}{l}\text { HB VI Th } \\
\text { 1855-1877 }\end{array}$ & $\begin{array}{c}\text { HB VII } \\
1877-1921\end{array}$ & $\begin{array}{c}\text { HB VIII } \\
\text { 1921-1939 }\end{array}$ & $\begin{array}{c}\text { HB IX } \\
1940-1988\end{array}$ & $\begin{array}{c}\text { HB X } \\
\text { 1989-Skrng }\end{array}$ \\
\hline $\begin{array}{l}\text { Busana } \\
\text { Raja } \\
\text { secara ke } \\
\text { seluruh } \\
\text { an }\end{array}$ & & & & & \\
\hline
\end{tabular}




\section{$3 \quad$ Kesimpulan}

Busana adalah sebuah ekspresi budaya, keragaman busana kerkait dengan status sosial seseorang. Masyarakat Jawa mermiliki strata sosial yang berlapislapis, raja dianggap memiliki status paling atas kemudian lapisan bangsawan, golongan priyayi, lapisan saudagar, dan lapisan petani atau rakyat biasa.

Sejak pasca perjanjian Giyanti tahun 1755, busana raja kerajaan Surakarta dan Yogyakarta secara turun temurun, berfungsi sebagai pusaka kerajaan yang disakralkan. Karakter busana raja Surakarta dan Yogyakarta dipengaruhi oleh situasi politik, keadaan ekonomi, status sosial, perkembangan budaya pada zaman kekuasaan raja-raja yang bersangkutan memerintah, sehingga busana kebesaran setiap raja yang berkuasa selalu mengalami perubahan terutama pada pelengkapnnya termasuk tanda-tanda kebesarannya pada saat pemerintahannya.

Hasil penelitian menunjukkan bahwa faktor-faktor yang mempengaruhi perubahan dan perbedaan gaya busana raja dari kepala sampai alas kaki pada raja-raja Surakarta dan Yogyakarta tidak selalu berhubungan nilai simbolisnya saja, tetapi juga terdapat upaya kreatif untuk membedakan antar raja yang berkuasa . Hal itu terbukti adanya pergeseran dan perubahan pada bentuk mahkota (kuluk atau panunggul), baju sikepan ageng bordiran bleggen, perhiasan (accessories), celana cinde (lancingan atau sarual), kampuh blumbangan dengan batik bermotif parang barong, pedang pendek (pasikon wedhung), keris sebagai ciri status sosial, sabuk (ukup) sepasang potongan kain dibagian kepuh belakang, dan selop (alas kaki) yang dipakai raja.

\section{Daftar Pustaka}

[1] Honggopuro, Kalinggo. 2002. Batik Sebagai Busana dalam Tatanan dan Tuntunan. Yayasan Peduli Karaton Hadiningrat, Surakarta, p. 8.

[2] Moedjanto G. 1994. Kasultanan Yogyakarta dan Kadipaten Pakualaman. Yogyakarta: Kanisius, p. 68.

[3] Saparto. 1969. Riwayat singkat karaton Surakarta, pp. 9, 19-22.

[4] Kusumodilaga. 1990. p. 162.

[5] Sajid.1984. Babad Sala, Rekso Pustoko Istana Mangkunegaran, Surakarta, pp. 13-22.

[6] Dalyono, Moh. 1939. Ketataprajaan Mangkunegaran, Terjemahan Sarwanto W., Surakarta: Reksopustoko, p. 8.

[7] Suroto. 1983. p. 20. 
[8] Yosodipuro. 1987. p. 9.

[9] 1996. Mbangun Tuwuh, p. 6.

[10] Soeharto. 1985. pp. 22-23.

[11] Moedjo. 1994. p. 12.

[12] Poerwokusumo, Soedarisman. 1985. pp. 8, 24, 37.

[13] Sumardjan, Selo. 1991. p. 23.

[14] Brongtodiningrat, K.P.H. 1978. Arti Kraton Yogyakarta, diterjemahkan oleh R. Murdani Hadiatmaja, p. 8.

[15] Sukanto. 1952. Sekitar Jogjakarta 1755-1825, p. 200-201.

[16] Soekanto, Soerjono. 1990. pp. $311-312$.

[17] Condronegoro, Mari S. 1995. Busana Adat Kraton Yogyakarta, Yayasan Pustaka Nusatama, Yogyakarta.

[18] Moedjanto, G. 1994. Kasultanan Yogyakarta \& Kadipaten Pakualaman : tinjauan historis dua praja kejawen antara 1755-1992, p. 109.

[19] Gesick. 1989. p. 17.

[20] Wiyoso. 1983. p. 53.

[21] Wirjosuparto. 1964. p. 4.

[22] Suyanto. 1986. pp. 71-73. 